\title{
В аппарате Уполномоченного по правам человека в Российской Федерации
}

С этого намера редакция отркрывает новую рубрику, в которой будут пуликоваться материаль о международно-парвовьх аспектах деятельности Уполнамоченного по правам человека в Российской Федерации. *

1. Уполномоченынй по правам человека в Российской Федерации: новый конституционный институт

Институт Уполномоченного по правам челвоека является новым для России. Должность Уполномоченного по правам челвоека учреждена Конституцией Российской Федерации 1993 года. Пункт "д" части 1 саттьи 103 Конституции относит к ведению Государственной Думы назначение и освобождение от должности Уполномоченного, действующего в соответствии с Федеральным конституционным закоHOM.

Федеральный конституционпый закон "Об Уполномоченном по правам человека в Российской Федерации" 25 декабря 1996 года был принят Государственной Думой, 12 февраля 1997 года одобрен Советом Федерации, 26 февраля 1997 года подписан Президентом Российской Федерации, 4 марта 1997 года официально опубликован и вступил в силу. Он определил статус Уполномоченного, его компетенцию, порядок назначения и освобождения от должности.

Должность Уполномоченного по правам человека в Российской Федерации учреждена в целях обеспечения гарантий государственной защиты прав и свобод граждан, их соблюдения и уважения государстенными органами, органами местного самоуправления, должностными лицами и государственными служашими. Уполномчоенный при осуществлении своих полномочий независим и неподотчетен каким-либо

* Данный материал подготовлен советником международного отдела аппарата Уполномоченного по правам человека в Российской Федерации А. И. Лебедевым. 
государственным ораганм и должностным лицам. Деятельность Уполномоченного дополняет сушествуюшие средства зашиты прав и свобод граждан, не отменяет и не влечет пересмотра компетенции государственнњх органов, обеспечивающих зашиту и восстановление нарушенных прав и свобод.

Уполномоченный по правам челвоека в Российской Федерации при осушествлении своих обязанностей пользуется привилегиями и иммунитетами по аналогии с теми, которые предусмотрены Статьей 40 Устава Совета Европы и положениями соглашений и конвенций, заключенных на ее основе.

Уполномоченный осушествляет зашиту прав человека, руководствуясь Конституцией Российской Федерации, законодательством Российской Федерации, а также нормами международного права и международными договорами.

Международное определение института Уполномоченного (омбудсмена) - государственная служба, предусмотренная конституцией и возглавляемая независимым публичным должностым лицом высшего ранга, которое ответственно только перед законом.

Назначение Уполномоченного в государственном механизме состоит в том, чтобы контроливать баланс между тремя центрами власти в государстве: законодательным, исполнительным и судебным. Компетенция Уполномоченного не имеет ограничений, связанных с деятельностью высших государственных органов, вооруженных сил, внутренних дел. Согласно статье 2 Федерального конституционного закона "Об Уполномчоенном по правам человека в Российской Федерации" все решения Уполномоченного (в том числе заключения) не подлежат обжалованию и пересмотру никакими государственными органами.

Основными направлениями деятельности Уполномоченного по правам человека в Российской Федерации являются:

- рассмотрение жалоб и обращений о нарушениях прав и свобод человека и гражданина, принтие мер по их восстановлению;

- анализ законодательства Российской Федерации в области прав человека и гражданина, подготовка рекомендаций по его совершенствованию и приведению в соответствие с общепризнанными приншипами и нормами международного права;

- развитие международного сотрудничества в области прав человека;

- правовое просвещение по вопросам прав и свобод человека, форм и методов их защиты;

- информирвоание органов государственной власти и обшественности о положении дел с соблюдением прав и свобод граждан в Российской Федерации.

Уполномоченный готовит ежегодный доклад о своей деятельности, а также направляет в Государственную Думу специальные доклады по отдельным вопросам соблюдения прав и свобод граждан в Российской Федерации.

Для обеспечения деятельности Уполномоченного создан рабочий аппарат, включающий пресс-службу, отраслевые отделы (конституци- 
онного и административного права, гражданского права и жилищного законодательства, по земельным спорам, трудового законодательства, утоловного права, по делам ветеранов, по жалобам военнослужащих, по рассмотрению жалоб беженцев), отдел по связям с субъктами РФ и с правозащитными организациями, международный и информационноаналитический отделы, а кроме того - адмиинстративно-технические службы.

22 мая 1998 года Государственной Думой тайным голосованием на должность Уполномоченного по правам человека в Российской Федерации назначен доктор юридических наук, профессор О. О. Миронов.

$$
\star \star \star
$$

Уполномоченный по правам человека в Российской Федерации и его аппарат размещаются по адрсу: 103084 г. Москва, Мясницкая ул., 47. Телефоны: $207-34-12,207-32-20$, факс 207-39-77.

2. Выступление Уполномоченного по правам человека в Российской Федерации в защиту свободы советси

В соответствии с частью 2 статьи 31 Федерального конституционного закона "Об Уполномоченном по правам человека в Российской Федерации" по результатам изучения и анализа информации о нарушении прав и свобод граждан, обобщения итогов рассмотрения жалоб Уполномоченный вправе обращаться к субвектам права законодательной инициативы с предложениями об изменении и о дополнении федерального законодательства в случае, если законодательство противоречит общепризнанныим принципам и нормам межсдународного права и межсдународным договорам Российской Федерации.

По итогам рассмотрения Федерального закона "О свободе совести и о религиозньх объединениях" в Комитет по делам общественньх объединений и религиозньх организаций Государственной Думы Федерального Собрания Российской Федерации направлено предложение Уполномоченного о внесении изменений и допалнений в этот закон, к которому прилагалось следующее Заключение.

Заклочение Уполномоченного по правам челвоека

в Российской Федерации

\section{ФЕДЕРАЛЬНЫЙ ЗАКОН "О СВОБОДЕ СОВЕСТИ И О РЕЛИГИОЗНЫХ ОБЪЕДИНЕНИЯХ” И МЕЖДУНАРОДНО-ПРАВОВОЫЕ ОБЯЗАТЕЛЬСТВА РОССИЙСКОЙ ФЕДЕРАЦИИ}

Принятый 26 сентября 1997 г. Федеральный закон “О свободе совести и о религиозных объединениях" в основном отвечает международно-правовым обязательствам России, взятым ею на себя в качестве государства-участника Международного пакта о гражданских и политических правах и Европейской Конвенции о защите основных прав и свобод человека. В преамбуле Закона (пункты 1-3), как и в статьях 28, 19 (ч. 2) и 29 (ч. 2) Конституции Российской Федерации, подтверждается 
право каждого на свободу совести и свободу вероисповедания, а такое на равенство перед законом независимо от отношения к религии и убеждений.

В то же время ряд положений Закона вступает в противореqие с принципами, установленными упомянутыми международно-правовыми документами и, соответственно, может быть опротестован гражданами при подаче жалоб в Европейский Суд по правам человека. По сути дела эти нормы и не могут действовать на территолрии Российской Федерации, исходя из примата над внутренним законодательством правил, установленных международными договорами, что предусмотрено Конституцией РФ (т. 4 ст. 15).

1. По сравнению с общим международно-правовым принципом равенства всех религий, зафиксированным в Конституции Российской Федерации (согласно ч. 1 ст. 14 "никакая религия не может устанавливаться в качестве государственной или обязательной”, а согласно ч. 2 этой же статьи “релегиозные объединения... равны перед законом"), в Законе о свободе совести по сути закрепляется привилегированное положение отдельных религий.

В преамбуле Закона (п. 4-5) делается ссылка на "особую роль православия в истории России, в становлении и развитии ее духовности и культуры" и на уважсние "христианства, ислама, буддизма, иудаизма и других религий, составляющих неотьемлемую часть исторического наследия России".

Возникает два вопроса. Во-первых, какие религии подпадают под определение "других" - католицизм, униатство, или же, скажем, пятидесятники и молокане, которые также могут рассматриваться как часть исторического наследия России. Во-вторых, означает ли это неуважение к другим религиям, не поименованным в Законе - конфуцианству, индуизму и Т. П. - не являющимися частьк этого наследия. При нынешних формулировках преамбулы строгого кридического ответа на эти вопросы не существует.

2. В Законе о свободе совести (п. 3 ст. 3) говорится, что установление преимуществ, ограничений или иных форм дискриминации в зависимости от отношения к религии не допускается. Однако, помимо декларированного в преамбуле привилегированного положения отдельных религий, ряд друтих положений закона устанавливает нормы, по сути ведущие к дискриминации отдельных конфессий на практике.

Противоречит как Европейской конвенции, так и прецедентам органов Совета Европы, являющимся важным источником “европейского" права, проводимое в Законе (ст. ст. 6 и 7) разграничение между религиозными объединениями и религиозными группами.

В соответствии с п. 1 ст. 7 Закона религиозные группы, в отличие or релитиозных объединений, не поделжат государственной регистрации и не пользуются правами кридического лица.

Закон, кроме того, проводит различие между "традиционными" религиозными организациями и религиозными организациями, у которых отсутствует "документ, подтверждающий их существование на соответствующей территории не менее 15 лет” (п. 1 ст. 9 Закона). 
“Нетрадиционные" религиозные организации лишены многих прав и в соответствии с п. 3 ст. 27 Закона не могут:

- просить Президента РФ об отсрочке от призыва на военную службу и освобождении от военньх сборов своих священнослужителей, а также не имеют права на замену военной службы альтернативной службой для последователей данной религии;

- создавать образовательные учреждения;

- обучать детей религии вне рамок образовательной программы;

- иметь при себе представительство иностранной религиозной организации;

- проводить релитиозные обряды в лечебно-профилактических и больничных учреждениях, детских домах, домах-интернатах для престарелых и инвалидов, в учреждениях, исполняющих уголовное наказание в виде лишения свободы;

- производить, приобретать, экспортировать, импортировать и распространять религиозную литературу, печатные, аудио- и видеоматериалы и иные предметы религиозного назначения;

- учреждать организации, издающие богослужебную литературу и производящие предметы культового назначения;

- создавать образователыные учреждения, а также учреждать средства массовой информации;

- создавать учреждения профессионального религиозного образования для подготовки служителей и религиозного персонала;

- приглашать иностранных граждан для занятия профессиональной, в том числе проповеднической, религиозной деятельностью.

Дискриминационным является также противоречащий как Европейской Конвенции, так и Международному пакту о гражданских и политических првах п. 2 ст. 13 Закона, который гласит, что "представительство иностранной религиозной организации не может заниматься культовой и иной деятельностью, и на него не распространяется статус релитиозного объединения".

3. Согласно п. 2 ст. 3 Закона о свободе совести "право человека и гражданина на свободу совести и свободу вероисповедания может быть ограничено Федеральным законом только в той мере, в какой это необходимо в целях защиты основ конституционного строя, нравственности, здоровья, прав и законньх интересов человека и гражданина, обеспечения обороны страны и безопасности государства".

Последнее положение противоречит п. 2 ст. 9 Европейской конвенции о защите прав человека и основных свобод, который гласит: "свобода исповедовать свою религию... поделжит лишь таким ограничениям, которые установлены законом и необходимы в демократическом обществе в интересах общественного спокойствия, охраны общественного порядка, здоровья и нравственности или для защиты прав и свобод других лиц". Это - исчерпывающий список предусмотренных Конвенцией законных ограничений права на свободу религии. В отличие от ряда других прав и свобод, гарантируемых, в частности, статьями $8,10,11$, никакого лимитирования свободы религии по соображениям "национальной безопасности” Конвенция не устанавлвает. 
4. Ч. 3 и 4 ст. 16 Закона о свободе совести предусматривают возможность совершения религиозных обрядов и церемоний в воинских частях, в местах лишения свободы и местах содержания под стражей. Однако практические гарантии реализации этих прав в Законе отсутствуют. Не ясно, что имеется в виду под "учетом требований воинских уставов" и "соблюдением требований уголовно-процессуального законодательства", на которые ссылается данная Статья.

С учетом изложенньх замечаний Федеральный закон "О свободе совести и религиозньх объединений" может быть приведен в соответствие с общепризнанными принципмм и нормами международного права и международными договорами Российской Федерации.

14 мая 1999 года Постоянная палата по правам человека Политического консультативногос овета при Президенте Российской Федерации провела слушания, в центре которьх находилось выщеприведенное Заключение.

Большинство выступивших отметили своевременность и правильность постановки в Заключении вопроса о необходимости внесения изменений и дополнений в закон с иелью приведения его в соответствие с положениями международных договоров по правам человека, в которьх участвует Россия, прежде всего Международного пакта о политических и гражданских правах и Европейской Конвенции о защите прав человека и основньх свобод. Поддержаны были и основные концептуальные положения Заключения.

- Председатель Палаты депутат Государственной Думы В. В. Борщев отметил, что Закон в его нынешней форме нарушает права верующих различньх конфессий, включая православную, и может лишь способствовать развитию в России межрелигиозной вражды по югославкому сценарию. Практика применения Закона свидетельствует о том, что местные власти во многих регионах, руководствуясь положениями преамбулы Закона, произвольно толкуют все его положения в пользу русской православной церкви, ущемляют права верующих других конфессий на проведение своих служб.

Сопредседатель Славянского правового центра В. В. Ряховский информировал о многих случаях прямых нарущений прав религиозных объединений и верующих на основе положения Закона. Он пдиеркнул, что правозащитными и религиозными организациями позитивно воспринят интерес Уполномоченного по правам человека к данной проблеме и стремление найти ее позитивное решение.

На слушаниях выступили также представители религиозньх конфессий, видные правозащитники.

По итогам слушаний принято Решение Постоянной палаты по првам человека Политического консультативного совета при Президенте Российской Федерации, в котором подчеркивается, что правоприменительная практика, сложсившаяся за палтора года действия Закона, показывает, что не только откровенно дискриминационные, но и многие другие положения Закона, в силу их двусмысленности, приводят к грубым нарушениям прав человека, прежде всего в отнощении общин верующих в субвектах Российской Федерачии. Постоянная палата всецело поддержала позицию Уполномоченного по правам человека в Российской Федерации, выраженную 
в его заключении на Закон, и присоединилась к его предложению привести Закон в соответствие с общепризнанными принципами и нормами международного права и межсународными договорами Российской Федерации.

3. Уполномоченный по правам человека в Российской Федеращии о несоответствии международно-правовым обязательствам России Закона "О милиции"

В Комитет по законодательству и судебно-правовой реформе Государственной Думы Федерального Собрания Российской Федерации направлено следующее Заключение Уполномоченного.

\section{Заключение Уполномоченного по правам человека}

в Российской Федерации

\section{О НЕСООТВЕТСТВИИ ПОЛОЖЕНИЙ ЗАКОНА "О МИЛИЦИИ", ДОПУСКАЮЩИХ ПРИМЕНЕНИЕ СИЛЫ, СТАТЬЕ 3 ЕВРОПЕЙСКОЙ КОНВЕНЦИИ О ЗАЩИТЕ ПРАВ ЧЕЛОВЕКА И ОСНОВНЫХ СВОБОД}

Ст. 3 Европейской конвенции о защите прав человека и основных свобод запрещает пытки и бесчеловечное или унижающее достоинство обращение или наказание. СТ. 15 (ч. 2) Конвеншии не допускает никаких исключений или оговорок в вопросах соблюдения ст. 3.

В вопросах применения ст. 3 сложилась обширная практика органов Совета Европы, в частности в делах, касавшихся Греции, Северной Ирлаңдии и Турции, где речь шла о массовых нарушениях ее положений полицейскими органами.

В толковании Европейского Суда по правам человека бесчеловечное обращение или наказание - это причинение сильного физического или душевного страдания; унижающее достоинство обращение или наказание - это плохое обрашение такого рода, которое направлено на то, чтобы вызвать у жертв чувство страха, подавленности и неполноценности для того, чтобы оскорбить, унизить или сломить их физически и морально.

Главная задача Европейского Суда в любом деле, представленном по ст. 3 , состоит в том, чтобы определить, не свидетельствуют ли установленные факты о сложившейся адмиинстративной практике нарушения Конвенции. Чтобы определить существование такой практики, необходимы два элемента: повторяемость действий и официальная терпимость.

Под “повторяемостью действий" подразумевается значительное число случаев плохого обращения, которые отражают общую ситуацию. Схема таких действий может заключаться в том, что они предпринимаются сотрудниками одной и той же полиции или военного органа.

“Официальная терпимость" означает, что, хотя акты плохого обращения являются совершено незаконными, с ними мирятся в том смысле, что начальники тех, кто несет непосредственную ответственность, знают о таких актах, но тем не менее не предпринимают никаких действий, чтобы наказать за них или не допустить их повторения; или что вышестоящий орган, имея перед собой многочисленные утвержде- 
ния, проявляет безразличие, отказываясь провести надлежащее расследование в целях определения достоверности или недостоверности, или что при судебном разбирательстве не соблюдается беспристрастное слушание таких жалоб.

Практика деятельности органов милиции, существующая в России, может, в случае обрашения граждан с жалобами в Европейский Суд по правам челвоека, иметь результатом решение, констатируюшее наличие в России адмиинстративной практики бесчеловечного и унирающего достоинство обращения. Часть этих проблем коренится в дефектах действующего законодательства.

Хотя $§ 2$ ст. 5 действующего Закона РСФСР “О милиции” прямо указывает, что милиции запрешается прибегать к обрашению, унижаюешму достоинство человека, его ст. 13 предусматривает, что сотрудники милиции имеют право применять физическую силу, в том числе боевые приемы борьбы, для пресечения преступлений и административньх правонарушений, задержания лищ, их совершивших, преодоления противодействия законным требованиям, если ненасильственные способы не обеспечивают выполнения возложенных на милицию обязанностей. СТ. 14 этого же закона предоставляет сотрудникам милиции право применять специальные средства, имеющиеся на вооружении милищии, в частности, для выявления лиц, совершивших преступления.

Как представляется, в их нынешнем виде эти формулировки явлются дстаточно общими и допускают неоднозначное толкование, тем самым создавая усолвия для нарушения ст. 3 Европейской конвенции. В частности, такие административные правонаруешния, как нарушения правил дорожного движения, могут восприниматъся сотрудниками милиции как дающие ему право применять физическую силу, включая боеые приемы борьбы, подпадаюшие под понимание бесчеловечного или унижаюшего достоинство обрашения. Не предусмотрена ответственность начальников органов милищии за действия (бездействие), подпадающие под понимание "административной практики" нарушения ст. 3 Конвенции в трактовке Европейского Суда.

$\mathrm{K}$ сожалению, Федеральный закон "O внесении изменений и дополнений в Закон РСФСР "О милиции" от 31 марта 1999 г. не учитывает требований Европейской Конвенщии. В нем лишь дополнен перечень специальных средств электрошоковыми устройствами.

В этой связи необходимо уточнить те положения Закона о милиции, которые оставляют большую свободу действий и субъективной оценки ситуации сотрудниками милиции.

Для этого следует дополнить Закон положениями о том, что применение физической силы и специальных средств в случаях, составляющих малую обшественную опасность, квалифицируется как бесчеловечное или унижающее достоинство обращение и влечет за собой ответственность, установленную законом и подобную же ответственность несут начальники органов милиции, своим действием или бездействием допускаюшие повторение подобных случаев. Одновременно в закон требуется ввести определения терминов "ненасильственные способы" и "малая общестенная опасность", например установив ограничительный перечень административных правонарушений, не допускающих приме- 
нения насильственных способов, со ссылкой на соответствующие положения Кодекса об административньх правонарушениях.

4. Обращение Уполномоченного с просьбой дать толкование положений Конституции Российской Федерации, относящихся к международным договорам

В письме Уполномоченного по правам человека в Росийской Федерации Председателю Комитета по законодательству и судебно-правовой реформе и Председателю Комитета по международным делам Государственной Думы отмечена озабоченность проблемой защиты прав российских граждан, находящихся в г. Байконур. О. О. Миронов высказал рекомендацию об учреждении должности Уполномоченного по правам человека в г. Байконуре как субъекте Российской Федерации. Такую правовую возможность открывает положение 3 п. 1 ст. 1 росийскоказахстанского Соглашения о статусе города Байконур, согласно которому на весь период аренды у Казахстана этот город "наделяется статусом, соответствующим городу феедрального значения Российской Федерации".

В то же время, говорится в письме, обращает на себя внимание, что российско-казахстанские соглашения по Байконуру содержат положения, которые могут рассматриваться как изменяюшие ряд норм Конституции Российской Федерации. Тем самым создается возможность массового нарушения прав и свобод российских граждан по смыслу ст. 21 Федерального конституционного закона "Об Уполномоченном по правам человека в Российской Федерации".

Ст. 15 (ч. 4) Конституции РФ устанавливает, что если международным договором Российской Федерации установлены иные правила, чем предусмотренные законом, то применяются правила международного договора. Ст. 125 (п. " $r$ " ч. 2) запрещает Конституционному Суду РФ проверять конституционность вступивших в силу международньх договоров. Таким образом, создается неопределенность в вопросе о том, следует ли указанные выше положения Конституции РФ понимать как допускаюшие возможность внесения в нее изменений и дополнений международными договорами РФ, т. е. в порядке ином, нежели установленный ее ст. ст. 134-137.

В соответствии с ч. 5 ст. 125 Конституции Российской Федерации, ст. 21 и ч. 2 ст. 31 Федерального конституционного закона "О6 Уполномоченном по правам человека в Российской Федерации" и ст. 105 Федерального конституционного закона "О Конституционном Суде Российской Федерации" О. О. Мирнов попросил предприянть шаги по направлению от имени Государственной Думы обращения в Конституционный Суд Российской Федерации с запросом о толковании ч. 4 ст. 15, п. "г" ч. 2 и ч. 6 ст. 125 Конституции Российской Федерации.

K письму в Государственную Думу приложен следующий справочный материал. 


\section{О ПРОБЕЛМЕ КОНСТИТУЦИОННЫХ ПРАВ ГРАЖДАН РОССИЙСКОЙ ФЕДЕРАЦИИ, ПРОЖИВАЮЩИХ В Г. БАЙОНУР}

Правовой статус космодрома "Байконур" и г. Байконур (Ленинска) определяется Соглашениями между Российской Федерацией и Республкой Казахстан об основнњх принципах и условпях использования космодрома "Байконур" от 28 марта 1994 г., о статусе города Байконур, порядке формирования и статусе его органов исполнительной власти от 23 декабря 1995 г. и межправительственным Договором аренды комплекска "Байконур" от 10 декабря 1994 г.

K сожалению, эти документы содержат ряд положений, которые могут нарушить конституционные права граждан Российской Федерации, находящихся на территории комглекса "Байконур".

1. П. 6.9 ст. 6 Договора аренды предусматривает, что глава администрации города Ленинска "назначается совместно Президентом Российской Федерации и Президентом Республики Казахстан по представлению Российской Стороны". Это не входит в полномочия Президента Российской Федерации, установленные в ст. ст. 83, 84, 86 и 89 Конституции, а также противоречит нормам о местном самоуправлении, включенным в ее Главу 8. Более того, подписывая Договор аренды, Правительство Российской Федерации вышло за рамки своей компетенции, поскольку было не вправе вносить изменения в перечень полномочий Президента.

2. В соответствии с $\S 3$ п. 1 ст. 1 Соглашения о статусе города Байконур на весь период аренды этот город "наделяется статусом, соответствующим городу федерального значения Российской Федерации". Однако п. 1 ст. 65 Конституции указывает в числе субъектов Российской Федерации только два города федерального значения Москву и Санкт-Петербург. Поэтому встает вопрос - является ли город Байконур субъетом Российской Феедрации или нет с соответствуюшими последствиями для прав проживающих там граждан (в частности, права на учреждение должности Уполномоченного по правам человека).

3. П. 1 ст. 5 Соглашения о статусе города Байконур предусматривает, что органы городской представительной власти в городе Байконур не формируются. В соответствии с $\S 3$ ст. 6 городскую администрацию формирует Правительство Российской Федерации. Это прямо противоречит п. 1 ст. 131 и ст. 133 Конститушии.

4. П. 1 ст. 14 Соглашения о статусе города Байконур устанавливает особый режим проживания граждан,в ключающий ограничения на въезд и выезд, ограничение на право передачи в собственность недвижимого имушества, ограничения на право заниматься определенынми видами деятельности. Эти положения вступают в противоречие со статьями 55 и 56 Конституции.

t $x+2$

Соглашение между Российской Федерацией и Республикой Казахстан о статусе города Байконур, порядке формирования и статусе его органов исполнительной власти от 23 декабря 1995 г. и межправитель- 
ственный Договор аренды комплекса "Байконур" от 10 декабря 1994 г. были ратифицированы в форме соответствующих федеральных законов. Тем самым Конституционный Суд РФ не может решить вопрос об их соответствии Конституции, поскольку его компетенция, в соответствии с п. "г" ч. 2 ст. 125 Конституции, распространяется только на не вступившие в силу международные договоры. Поэтому не может быть применено и положение ч. 6 той же статьи о том, что не соответствуюшие Конституции Российской Федерации международные договоры Российской Федерации не подлежат введению в действие и применению.

Создавшаяся ситуация требует обрашения в Конституционный Суд Российской Федерации с запросом о толковании ч. 4 ст. 15 и ч. 6 ст. 125 Конституции Российской Федерации, а именно, может ли международный договор изменять положения Конституции Российской Федерации и должен ли он применяться, если не соответствует им, однако был ратифищирован в форме федерального закона.

Статья поступила в редакцию в июле 19992. 